\title{
Effective Teaching System Building of Applied Engineering Colleagues For the Employment
}

\author{
Li Sun ${ }^{1,2, a}$, Min Sun ${ }^{1, b}$, Zhiguo Zhao ${ }^{1, b}$ \\ ${ }^{1}$ Huaiyin Institute of Technology, Huai'an, 223003, China \\ ${ }^{2}$ Jiangsu University, Zhenjiang, 212013, China \\ aemail: sunli0124@163.com, bemail:Inzzg @163.com
}

Keywords: Effective teaching; system building; applied engineering colleague; for the employment

\begin{abstract}
In order to improve employment rate of local applied engineering colleagues, and enhance the satisfaction of employer for the students, an effective teaching system for the employment of local applied engineering colleagues is built. The system consists of four aspects: the focus on effective classroom teaching, strengthen effective practice, effective assessment and to strengthen flexible teacher management. In this way, the system can ensure a gradual increase of the teaching level and the overall quality enhancement of all students of the local applied engineering colleagues.
\end{abstract}

\section{Introduction}

Applied undergraduate institutions is a high education type between research universities and vocational. It takes the applied talents training as the main task and objective, which is different from the research university who training research personnel and the vocational who training the skilled personnel. Only the engineering colleges of the application colleges are considered, so the data of Huaiyin Institute of Technology are used in the paper.

In order to improve the teaching effectiveness and teaching quality, Chinese college teachers conduct much research for teaching method and teaching strategy. Doctor Xiao Chuan of the Beijing Normal University explores the effective teaching characteristics of the university from the education, psychology and philosophy etc.. He believes that the effective teaching characteristics of the university are to give the deep culture infection and take care to the students, pay attention to the teaching process, and the teacher has the distinct methodological awareness [1-4]. Weihong and ShenJiliang of Beijing Normal University require students to evaluate the teaching of the teachers according to the teaching evaluation table, the result shows the teacher characteristics of the effective teaching include that the students' ability improved by the teacher's teaching, clear express of the teacher, distinctive teaching style and characteristic of the teacher, teachers have responsible for teaching, teaching key and difficult contents prominent, and the teachers can stimulate the students' interest and initiative.

\section{Connotation and Ideas of Effective Teaching}

Referred to effective teaching, many scholars have given more defines according to the different objects and teaching characteristics. Aimed to the teaching characteristics of engineering colleges, the effective teaching connotation is given as follow: effective teaching is a kind of teaching activities the teacher follows the teaching objective law, at the optimal speed, effectiveness and efficiency to promote the students to achieve "three dimensions objects", which are knowledge and skills, process and methods, and attitudes and values, make the students sustainable progress and development in order to meet the education value of the social and personal needs.

Effective teaching is the effectiveness of the teaching process, which is in accordance with the teaching law, is effective teaching and efficient teaching. Contrary to the teaching law, the teaching of no effect, negative effect and the low efficiency is not the effective teaching. Accordingly, the definition of effective teaching is as follows: it's a teaching of the teacher causes, maintains and 
promotes successfully the students' studying by the efficient teaching process, and relatively effectively achieves the expected teaching effectiveness [5].

Taking the application engineering colleges as the research object, effective teaching ideas includes five aspects: concerned about the students' progress or development, teaching effectiveness, the measured or quantified, the reflective consciousness of the teacher and specific teaching strategies. The practice of effective teaching ideas, that is combined with the characteristics of the applied engineering colleges, in the progress of developing "highly qualified field engineers”, efficient implementation the concept of effective teaching [6].

\section{Problems in the Teaching of Local Application Engineering Colleges}

In recent years, the evaluations of the students for the teacher and the business for the graduates indicate that teaching quality of the general colleges are declining, and mostly graduates reflect the learned knowledge in the school do not work in the jobs. For applied general engineering colleges, the jobs of the graduates are field engineers at this stage, the students, learn ability and learn environment have the certain characteristics and regularity.

The students of local applied engineering college have a lower academic level. With the popularity of mobile phones, network and else electronic products, a lot of poor self-control students are addicted to the games to abandon learning. The biggest advantage of the local applied engineering college is the higher practical ability, can quickly integrate into the work and serve the local development. However, many students can not correctly recognize the employment position, can not be a good plan for their own, resulting in the students see the differences of the local college with the research university, simply complaining about the weakness of the applied engineering college. The students are not acquainted with the employment direction, especially cannot grasp the employment opportunities of practicing in grass roots and training, feeling they are college students, should engage in "high level" business and can not find the right job. The status of some students is they don't know what they need to learn, and don't know what kind of work they want.The teaching management system of the local applied engineering college is not perfect.The teaching assessment requirement and the system are lack of flexibility. Practice teaching pays too much emphasis on the report writing, there is no emphasis on the practice process and ability.

\section{Effective Teaching System Construction of Applied Engineering College}

After development of decades, the thinking mode of effective teaching from a single to comprehensive development, the research at this time is not limited to the teachers' quality or teaching behavior, but trying to examine effective teaching from the multi-dimensions. Therefore, aimed to the existing questions of effective teaching in the local engineering college, from the four aspects of classroom-practice-assessment-teacher management, an effective teaching system of "facing to jobs" is built. The system is shown as figure 1.

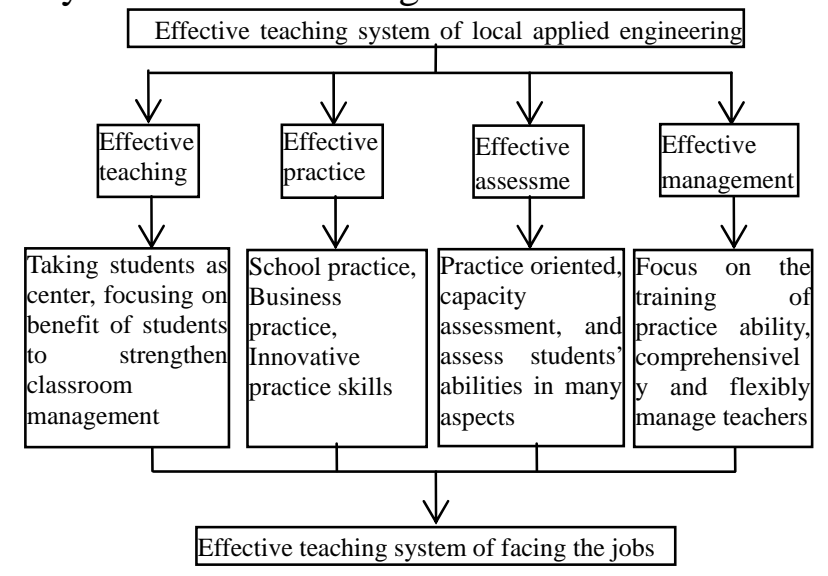

Fig.1 Effective teaching system of local applied engineering college.

In addition, the main content of the lectures is neither too theoretical, not to be too professional, 
but should be to integrate theory with practice, can provide the necessary basic theory and practice innovation in the post employment, also provide the necessary practical skills for future employment, to really different from research universities and vocational colleges.

Practice is one of the essential ability of applied engineering college students, so effective practice must be advocated by applied engineering college. The effective practice includes three aspects: school practices, business practices and innovation practical skills.

The basic course or experiment, practice, curriculum design (such as electric and electronic practice, metalworking practice, etc.) are arranged in schools, which be managed flexibly, the experimental site can be opened all days, the interesting students can always go to the laboratory; the teacher can manage by network and Q \&A online. This can provide the more relaxed learning environment for training students' practice skills.

There are at least 20 weeks are arranged for business practice, the practices and curriculum designs with related courses (such as product design, product manufacturing technology and product assembly practices etc.) and graduate design are unified arranged to the enterprises to conduct the corresponding position post practices. By the centralized internship can provide the real practice environment for students, and lay a solid foundation for the student employments. Many students work outstandingly, who can be directly left to the work.

The students can get some professional accreditation to offset credits during the university. Such as vehicle engineering students can take the certificate of senior workers, AutoCAD skills assessment certificate, or a variety of skills competitions and entrepreneurship competition awards, and technology innovation projects be offset against a certain credits. The specific innovation practices projects are shown as table 1.

Effective assessment is a test process for the students' learning and teachers' teaching quality. Therefore, according to the nature and characteristics of the different courses, the different assessment methods can be arranged: closed book exams, open book exam and write papers etc.. For the courses of closed or open book examination, the invigilation and marking works must be done to ensure the students are independent completion the examination content, which can examine the usual learning of the students and prevent cheating. For the courses of writing papers, the students must focus on new ideas, cannot cut copy and paste trouble.

The assessment is in addition to test the classroom teaching, can improve effectively teaching quality. If the assessment management is poor, the students can understand the situation, some students are not interested in the assessment will relax attitude towards learning to muddle through the assessment, such the teaching order will be worse and the teaching effectiveness can not be guaranteed. 
Table 1 Innovation practices projects

\begin{tabular}{|c|c|}
\hline Kinds & Projects \\
\hline $\begin{array}{l}\text { Disciplinary skills } \\
\text { competition }\end{array}$ & $\begin{array}{l}\text { Advanced Mathematics Contest, University Physics Competition, } \\
\text { College English Contest Mechanics Competition, Mathematical Contest } \\
\text { in Modeling, CNC technology race, computer design competition. }\end{array}$ \\
\hline Skills assessment & $\begin{array}{l}\text { Driver's license, maintenance workers, CAD certificate, Pro / E } \\
\text { certificate, UG certificate, etc.. }\end{array}$ \\
\hline $\begin{array}{l}\quad \text { Scientific anc } \\
\text { technological } \\
\text { innovation projects }\end{array}$ & $\begin{array}{l}\text { Advanced Mathematics Contest, University Physics Competition, } \\
\text { College English Contest Mechanics Competition, Mathematical Contest } \\
\text { in Modeling, CNC technology race, computer design competition. }\end{array}$ \\
\hline Practice innovation & $\begin{array}{l}\text { The university students' science and technology practice innovation } \\
\text { plans. }\end{array}$ \\
\hline $\begin{array}{l}\quad \text { Involved in the } \\
\text { project, fing publish } \\
\text { papers, filing patent }\end{array}$ & $\begin{array}{l}\text { Participation at all levels various topics, published various journal } \\
\text { papers and granted patents. }\end{array}$ \\
\hline Business practice & $\begin{array}{l}\text { Participate in enterprise product development, technological } \\
\text { innovation, testing and diagnosis, and other projects. }\end{array}$ \\
\hline Entrepreneurship & Entrepreneurship competition at all levels such as the Challenge Cup \\
\hline Competition & $\begin{array}{l}\text { National Undergraduate Science and Technology Work Design } \\
\text { Competition }\end{array}$ \\
\hline $\begin{array}{l}\text { Professional } \\
\text { competitions }\end{array}$ & $\begin{array}{l}\text { Students "Freescale" Cup smart car competition, Students Mechanical } \\
\text { Design and Innovation Competition of Jiangsu Province, China Robot } \\
\text { Competition and Robocup China Open etc.. }\end{array}$ \\
\hline
\end{tabular}

To increase teachers' practical skills training, in addition to improving the qualifications and titles of teachers, the teachers' practice ability of applied engineering colleges must meet some requirements, and therefore practical ability training for teachers are a regular basis.

Pay more attention to the teaching effectiveness of the teachers, increase the intensity of the supervision and peer with each other, find the problems in the process of the teaching to ensure the teaching quality, but not limited to whether or not to guarantee the teaching time. The practice should focus on teaching effectiveness, not only the students' internship reports, lab reports, but should examine the enhancement degree of students' practice ability. So, the teaching process and effectiveness should be monitored.

Emphasis on the teacher assessment, rather than focusing on the indicators of the assessment, especially for the poor class style, should be thoroughly governance. For example, the same teacher teaches the same course for 3 classes, the result is the pass rates of a class is over $20 \%$, while the other 2 classes are about $10 \%$.So the reasons of the students should be analyzed, rather than let the teacher review.

\section{Conclusion}

Effective teaching is the goal of all education institutions pursuit, especially the local applied engineering college. In order to enhance the students' practice ability, the effective teaching system for the jobs of the effective classroom teaching, effective practice, assessment and teacher management is constructed. The system helps enhance and improve the theoretical thinking of the effective teaching to enrich the theoretical system of the teaching, more importantly, which can provide a reference for teaching practice, improving teaching quality and training high-quality and high-level students.

\section{Acknowledgement}

The authors gratefully acknowledge the supports from Huaiyin Institute of Technology Education Research Projects (JYC201118 and JYC201117). 


\section{References}

[1] Sun Li, Liu Yongchen, ChangLv. Building of Applied Innovative Talents Training System in Local Colleges [J]. Research and Exploration in Laboratory, 2011(1) 143-145.

[2] Marsh, H.W., \&Roche, L.A. Making students' evaluations of teaching effectiveness effective [J]. American Psychologist, 1997, (52) 1187-1197.

[3] Chickering, A. W. and Gamson , Z. F. (eds) . Applying the seven principles for good practice in undergraduate education, New Directions for Teaching and Learning [M], Jossey-Bass Publishers, 1991.

[4] Wei Hong, Shen Jiliang. Study on Teaching Characteristics of Effective University Teacher[J]. Journal of Southwest China Normal University (Humanities and Social Sciences Edition), 2002, (28) 33-36.

[5] Yao Limin. The Elementary Approach to The Implications of Effective Teaching [J]. Modern University Education, 2004(5) 10-13. 